Sanjin Kodrić

Odsjek za književnosti naroda Bosne i Hercegovine

Univerziteta u Sarajevu, BiH

http://dx.doi.org/10.18778/8088-249-2.04

\title{
KAKO SU BOŠNJACI VIDELI MUSLIMANSKI ORIJENT I EUROPSKI ZAPAD KRAJEM 19. I POČETKOM 20. STOLJEĆA?
}

Kao autohtono muslimanski slavenski narod, Bošnjaci su i danas na specifičan način pozicionirani između muslimanskog Orijenta i evropskog Zapada, a što je, naravno, evidentno u različitim oblastima kulture Bošnjaka. Iako su apsolutni i apodiktični sudovi uvijek nezahvalni, vjerovatno danas najčešća i najpoznatija autorefleksivna predodžba u ovom smislu jeste slika Bošnjaka kao naroda na raskršću, ali i mosta između Istoka i Zapada. Obje ove predstave imaju i pozitivan i negativan emotivni karakter, tj. najčešće se doživljavaju i kao osobena prednost, ali i kao naročita zlosretnost bošnjačke kolektivne sudbine, a u njihovu reprezentiranju i u jednom i u drugom slučaju u značajnoj mjeri učestvovala je i književnost. U tom smislu, riječ je, dakle, i o svojevrsnim književnim predstavama $s$ važnim učincima i u izvanknjiževnoj sferi.

Ova, aktuelna slika Bošnjaka o sebi samima ima, međutim, dugu i složenu povijest, povijest koja ju je i oblikovala, a ona se također može pratiti i u književnoj prošlosti, i to kako u usmenoj, tako i u pisanoj književnosti. U usmenoj književnosti razumijevanje muslimanskog Orijenta i evropskog Zapada ostvareno je uglavnom na marginama epskog interesa za susret muslimanskog junaka, „gazije”, s „neprijateljem-nevjernikom”, odnosno „dušmaninom” i „kaurinom”, pri čemu se u usmenoj književnosti muslimanski Orijent i evropski Zapad uglavnom ne artikuliraju kao samobitni reprezentacijski fenomeni, odnosno ne ostvaruju se kao jasno zaokruženi imagologemi, kako će to biti slučaj u drugim tokovima bošnjačkog književnog stvaranja. U pitanju je, zapravo, prije svega tzv. krajinska tema, uvjetovana povijesnom činjenicom da je Bosna kao najzapadnija pokrajina Osmanskog carstva stoljećima bila granični prostor između muslimanskog i evropskog svijeta, a što je ono kako je Bosna doživljavana i iznutra, ali i izvana, kako se to pokazuje is druge strane granice, npr. u hrvatskoj usmenoj književnosti i kulturi ovogvremena [usp. Dukić 1998 i sl.]. Zato je odnosizmeđu muslimanskog Orijenta i evropskog Zapada u usmenom književnom stvaranju Bošnjaka sveden prvenstveno na karakteristični epski konflikt, s tim što treba naglasiti i postojanje nemalog broja primjera međusobnog uvažavanja protivnika kao junaka u skladu 
s naročitom epskom etikom, koja i neprijatelju ukazuje poštovanje upravo zbog njegova junaštva i junačke časti.

U pisanoj književnosti situacija je složenija. Naime, na bitno drugačije načine muslimanski Orijent i evropski Zapad imaginirani su u starijoj i novijoj bošnjačkoj književnosti kao dvama temeljnim podsistemima bošnjačkog pisanog književnog stvaranja. Izuzme li se pisano-književna tradicija srednjovjekovne Bosne, koja je zajednička osnovica bošnjačke, hrvatske i srpske književnosti u Bosni i Hercegovini, starija bošnjačka književnost nastajala je upravo u okvirima osmanske Bosne te bila cjelovito inkorporirana u književnu praksu osmanske, odnosno orijentalno-islamske interliterarne zajednice. To se posebno odnosi na književno stvaranje Bošnjaka na orijentalno-islamskim jezicima, turskom, perzijskom i arapskom, koje je dominantan dio starije bošnjačke književne baštine, pa je muslimanski Orijent bio ne samo neposredni već i izvorni kontekst starije bošnjačke književnosti. Uostalom, evropska kultura na Bosnu ovog vremena gledala je na identičan način u ovom smislu, a kako to između svega ostalog svjedoči i koncept Bliskog istoka, koji je, prema francuskom „Proche-Orient”, početkom 19. st. bio određen granicama Osmanskog carstva, uključujući i Bosnu.

$S$ druge strane, novija bošnjačka književnost pojava je koja se u bošnjačkom književnom stvaranju javlja upravo u onom trenutku kad Bosna zvanično prestaje biti dio muslimanskog Orijenta i kad postaje - ili kad je trebala postati - dio upravo evropskog Zapada. Ovakvo što uvjetovano je okupacijom Bosne od strane Austro-Ugarske monarhije 1878. godine, kad zahvaljujući odlukama Berlinskog kongresa Bosna po prvi put nakon više od četiri stoljeća osmanske vlasti u ovoj zemlji ulazi u zapadno-evropske okvire. U pitanju je, dakle, radikalni historijskodruštveni obrat, koji će ubrzo temeljito izmijeniti cjelinu Bosne, a naročito kulturu Bošnjaka. Kao dio upravo ovih promjena dolazi do neočekivanog okončavanja onog tipa kulture i književnog stvaranja koji je karakterizirao tradicionalnu bošnjačku kulturu, odnosno stariju bošnjačku književnost, te se u kontekstu stvaranja moderne bošnjačke kulture rađa i novija bošnjačka književnost kao onaj tok bošnjačkog književnog stvaranja unutar kojeg će se od tog trenutka pa nadalje ostvarivati književna praksa Bošnjaka [usp. Kodrić 2012].

U ovakvim okolnostima, vrijeme kraja 19 . i početka 20 . st. vrijeme je postepenog konstituiranja novije bošnjačke književnosti, a koje je u historiji bošnjačke kulture označeno imenom preporodnog doba [usp. Rizvić 1990]. Taj proces bošnjačka književnost, kao i bošnjačka kultura uopće, prolazila je teško i mučno, a nesumnjivo osnovo obilježje ovog vremena bilo je stanje kulturalne drame i traume, s jedne strane, dok je, s druge strane, razvoj bošnjačke književnosti u ovom trenutku bitno obilježen i stanjem njezine svojevrsne kolonijalne podređenosti u odnosu na novi, njoj dotad nepoznati, strani i tuđi zapadno-evropski kulturalni obrazac, a potom i postepenim oslobađanjem od kolonijalne svijesti [usp. Kodrić 2012]. Zato je u ovom procesu od ključne 
važnosti bilo upravo određenje Bošnjaka spram muslimanskog Orijenta kao njihova nekadašnjeg egzistencijalnog okvira i evropskog Zapada kao njihove nove neposredne životne realnosti.

\section{1.}

Ako bi se na načelnoj, općenitoj razini pokušalo odrediti to kako su Bošnjaci vidjeli muslimanski Orijent i evropski Zapad u svojem književnom stvaranju krajem 19. i početkom 20. st., onda bi se kao osobene konstante u ovom smislu dalo prepoznati nekoliko temeljnih pojava.

U prvom redu, to je pojava da se muslimanski Orijent i evropski Zapad u ovom trenutku imaginiraju kao već sasvim konkretne i jasne imagologeme, i to prije svega $\mathrm{s}$ funkcijom vlastitog bošnjačkog identitetskog određenja u poziciji između ova dva pola. I muslimanski Orijent i evropski Zapad postaju, naime, sad jasno prepoznatljive kategorije sa značenjem temeljnih i društvenih, kolektivnih, ali i individualnih vrijednosti i stavova, dvije slike svijeta i sebe u svijetu kako na razini egzistencije zajednice, tako i na razini egzistencije pojedinca. Ovakvo što održava podijeljenost bošnjačke zajednice ovog vremena na najmanje dvije strane, čije je postojanje „evidentirala” i bošnjačka književna praksa ovog vremena kao jedan od svojih ključnih, temeljnih predmetno-problemskih, tematskih interesa. Jednu stranu čine žestoki protivnici austrougarske okupacije Bosne, koji se ni na koji način ne mogu pomiriti s novom, austrougarskom vlašću, a koji evropski Zapad doživljavaju kao tuđi, strani, „,nevjernički” svijet, pa ili zahtijevaju iseljenje, „hidžru”, u „slobodni” dio Osmanskog carstva, najčešće u današnji Sandžak i Tursku, pod muslimansku vlast sultana i halife, ili, pak, ostaju u Bosni, povučeni iz života i neprijemčivi za bilo kakve promjene i prilagodbe, čekajući željeno skoro okončanje tuđinske vlasti i povratak Bosne u okrilje muslimanskog Orijenta, u Osmansko carstvo, a što je, inače, bila i mogućnost predviđena Berlinskim kongresom, koji je Austro-Ugarskoj monarhiji dao pravo tek privremene okupacije Bosne, dok je ona formalno i dalje bila pod osmanskim suverenitetom, sve do austrougarske zvanične aneksije 1908. godine. Druga strana u osnovi je jednako žalovala za "starim vaktom”, ali je manje ili više pomirljivije prihvatala „novo vrijeme” kao povijesnu datost i neizbježnost, te pritom tražila načine preživljavanja u novom povijesnom trenutku i njegovim izazovima, sve to uz krajnje rijetke optimističnije pristalice novog stanja, pogotovo u prvim godinama okupacije, a koji su i sami svoj nešto pozitivniji odnos prema evropskom Zapadu temeljili prije svega na činjenici povijesne nužnosti i svijesti o neizbježnosti sučeljavanja sa životnom realnošću te potrebi iznalaženja što boljih rješenja za novi životni trenutak cjeline zajednice. $S$ protekom godina, ove suprotnosti u značajnoj mjeri umanjivat će se, a muslimanski Orijent i evropski Zapad postajat će sve manje međusobno radikalno suprotstavljene kategorije, posebno 
s pojavom prve generacije koja se bitno intelektualno i duhovno oblikovala u austrougarskoj Bosni i Hercegovini.

O pitanjima evropeizacije u bošnjačkoj književnosti s kraja 19. i početka 20. st. još 1934. godine u knjizi Anfänge der Europäisierung im Kunstschrifttum der moslimischen Slaven in Bosnien und Herzegowina pisao je ugledni njemački slavist Maximilian Braun [usp. Braun 2009]. Prema Braunu, najveći strah u vezi s evropeizacijom kod Bošnjaka, posebno u počecima, predstavljao je strah od "evropeizacijekroz uništenje”. Kako to Braun također ispravno zapaža, prvenstveni cilj onih koji su pristali na činjenicu austrougarske okupacije Bosne bio je tek da se prihvate evropska „sredstva moći” uz i dalje kontinuiranje snažne duhovne veze s Osmanskim carstvom, odnosno s muslimanskim Orijentom uopće, a što također govori o karakteru viđenja muslimanskog Orijenta i evropskog Zapada kod Bošnjaka krajem 19. i početkom 20. st. Tako se ove imagologeme artikuliraju između ostalog i kao specifične postkonfliktne i posttraumatske predstave, a u njihovu oblikovanju, naročito tokom prvih godina nakon austrougarske okupacije Bosne, učestvuje s jedne strane i jaka kolonijalna prisila, dok se s druge strane sve više javlja i snažna vlastita emancipatorska težnja te pojava posebne vrste kulturalnog pragmatizma, tj. prihvatanja evropskog Zapada prije svega iz pragmatičnih razloga realne egzistencije. A to će reći da su se koncepti muslimanskog Orijenta i evropskog Zapada u bošnjačkoj književnosti te uopće kulturi s kraja 19. i početka 20. st. javili kao osobena reakcija na povijesnu činjenicu austrougarske okupacije Bosne, odnosno na niz radikalnih promjena koje se na ovoj osnovi dešavaju u bošnjačkoj zajednici i Bosni uopće, te da im je temeljna funkcija bila upravo razrješenje bošnjačke identitetske pozicije u novim povijesnim okolnostima. Pri svemu ovom, fokusira li se sama književna praksa kao takva, imagologeme muslimanskog Orijenta i evropskog Zapada u bošnjačkoj književnosti ovog vremena bitno su oblikovane i specifičnim obilježjima poetika romantizma i realizma, koji se u bošnjačkoj književnosti javljaju istovremeno upravo u ovom trenutku, i to u vidu tzv. folklornog romantizma i prosvjetiteljskog realizma preporodnog doba, hibridne poetičke pojave koja, naime, u skladu $\mathrm{s}$ njezinim ubrzanim književnim razvojem u novim kulturalnim prilikama dominantno karakterizira bošnjačku književnu praksu na kraju 19. i početku 20. st. [usp. Kodrić 2012].

\section{2.}

Ključne artikulacije predstava o muslimanskom Orijentu i evropskom Zapadu u bošnjačkoj književnosti s kraja 19. i početka 20. st. javit će se kod njezinih vodećih autora kakvi su, prije svih, Mehmed-beg Kapetanović Ljubušak (1839-1902), koji se s pravom smatra rodonačelnikom novije bošnjačke književnosti, i Safvet-beg Bašagić (1870-1934), stožerni autor novije bošnjačke 
književnosti na prijelazu dvaju stoljeća, odnosno kod drugih posebno važnih bošnjačkih autora ovog vremena poput npr. Osmana Nuri Hadžića (1869-1937), koji je pod pseudonimom Osman-Aziz s hrvatskim piscem iz Hercegovine Ivanom Milićevićem (1863-1950) objavio prvi bosanskohercegovački roman Bez nade (1895), Edhema Mulabdića (1862-1954), autora prvog bošnjačkog romana Zeleno busenje (1898), Muse Ćazima Ćatića (1878-1915), prvog bošnjačkog pjesnika moderne, i dr. Mehmed-beg Kapetanović Ljubušak prema evropskom Zapadu imao je u značajnoj mjeri izgrađen pozitivan odnos još i tokom posljednjeg desetljeća osmanske uprave u Bosni, kad se i sam bio uključio u proevropske modernizacijske procese koji su se u Bosanskom vilajetu dešavali u okvirima osmanskih tzv. tanzimatskih reformi u drugoj polovini 19. st. [usp. Rizvić 1990: 39-56, 101-105; Maglajlić 1987; Kodrić 2015a]. Ni u kojem slučaju ne odričući vrijednosti muslimanskom Orijentu te i dalje pišući i na orijentalno-islamskim jezicima, Ljubušak je još i prije kraja osmanske vlasti u Bosni u nekolika slučaja svoje radove objavio i na bosanskom jeziku i Vukovoj ćirilici, a koja se u Bosni u ovo vrijeme smatrala stranim, zapadnim pismom, budući da su Bošnjaci na maternjem jeziku u ovo vrijeme pisali prije svega na arapskom pismu prilagođenom glasovnom sistemu bosanskog jezika - arebici, a u pojedinim slučajevima i na staroj bosanskoj ćirilici - bosančici. Iako su tanzimatske reforme, koje je u Bosni provodio valija Topal Šerif Osman-paša, modernizacijske procese prikazivale prije svega kao izraze progresivnih snaga samog Osmanskog carstva, a ne kao neku vrstu kulturalnog podređivanja Evropi [usp. Kodrić 2015b], Ljubušak će pozitivan odnos prema zapadno-evropskoj kulturi zadržati i nakon austrougarske okupacije Bosne, pa će njegov cjelokupni kasniji rad biti posvećen upravo prihvatanju zapadno-evropskih vrijednosti među Bošnjacima. Pritom, Ljubušaku je osnovni cilj bio pomiriti muslimanski Orijent i evropski Zapad u Bosni, posebno u kulturalnom identitetu Bošnjaka, i u tom smislu integrirati ih u modernu Evropu njegova vremena, bez odricanja njihovih ključnih identitetskih određenja, naročito onih vezanih za religijsku, islamsku osnovu. Ljubušak je istovremeno insistirao i na zbližavanju Bošnjaka prije svega sa susjednim, njima srodnim južnoslavenskim narodima, njihovim književnostima i kulturama, tim prije što su upravo susjedne južnoslavenske književnosti i kulture Bošnjacima bile prva i najdostupnija veza s evropskim Zapadom, $s$ jedne strane, dok je, s druge strane, nastojao u istom ovom kontekstu promovirati i široj južnoslavenskoj kulturi predstaviti i vrijednosti muslimanskog Orijenta, pa tako i bošnjačku književno-kulturnu tradiciju. S ovim u vezi kod Ljubušaka je još iz vremena prije okončanja osmanske uprave u Bosni, a posebno kasnije evidentna i bliskost s panslavističkom idejom, pa će i njezini elementi oblikovati Ljubušakovo razumijevanje muslimanskog Orijenta i evropskog Zapada, naročito u smislu pozitivnog odnosa prema panslavenskoj uzajamnosti.

Ljubušakovo viđenje muslimanskog Orijenta i evropskog Zapada podrazumijeva, dakle, ideju integracije i sinteze te novog, ka zapadno-evropskoj 
kulturi otvorenog identiteta Bošnjaka, pri čemu će ovakve Ljubušakove i slične ideje ubrzo postati osnovna misao-vodilja za cjelokupni kulturni rad Bošnjaka krajem 19. i početkom 20. st., pa tako i svojevrsna platforma ukupnog bošnjačkog književnog stvaranja u preporodnom dobu. Sam Ljubušak, pak, posebno ih je ostvario u svojim sakupljačkim zbirkama Narodno blago (1887) i Istočno blago (I - 1896, II - 1897), dok ih je eksplicitno artikulirao u dvjema svojim brošurama, prvim takvim kod Bošnjaka - Što misle muhamedanci u Bosni (1886) i Budućnost ili napredak muhamedovaca u Bosni i Hercegovini (1893), kojima vrlo odlučno Bošnjake nastoji repatrirati u zapadno-evropski kontekst. Pri svemu ovom, međutim, posebno je zanimljiva upravo brošura Što misle muhamedanci u Bosni.

Riječje, naime, o Ljubušakovu publicističkom radu koji polemizira s anonimnom brošurom Bosniens Gegenwart und nächste Zukunft (1886), izvorno objavljenoj u „Lipskoj”, kako to kaže Ljubušak, odnosno u Leipzigu, a potom u skraćenom obliku štampanom u zagrebačkom listu Obzor, glavnom glasilu Hrvatske stranke prava krajem 19. i početkom 20. st. Kako to u svojoj studiji o Ljubušakovu književnom radu iz 1911. godine sažima Vladimir Ćorović, jedan od prvih prikazivača Ljubušakova djela, anonimna brošura svodila se na sljedeću ideju:

Muslimani su neprijatelji monarhije, anacionalni su, neradni, žive o tuđoj muci i vlada ne bi nikako trebala, da ih štiti i sprječava u iseljavanju. Pravoslavni imaju velikih mana i jedini su katolici, na koje se uprava može i mora osloniti, naravno uz prvi uslov, da Kalaj prestane s mađarizacijom u zemlji. [Ćorović 2008: 151]

U ovakvom kontekstu, Ljubušakova polemika otkriva, dakle, neke od ideoloških okolnosti šireg okvira unutar kojega se kod Bošnjaka krajem 19. i početkom 20. st. uspostavljala njihova slika muslimanskog Orijenta i evropskog Zapada. Radi se, naime, o poznatim devetnaestostoljetnim, romantičarskim velikonacionalnim težnjama na Slavenskom jugu koje su, nerijetko i pod krinkom upravo njihove evropeizacije, bosanske muslimane nastojale "nacionalizirati” u svoj nacionalni korpus, u pravilu hrvatski ili srpski, s jedne strane [usp. Isaković 1990], dok je s druge strane u pitanju karakteristično orijentalističkoevropocentrično stereotipno razumijevanje Bošnjaka, a što je svakako predstavljalo i neminovan izazov za bošnjačko pozitivno percipiranje evropskog Zapada i mogućnosti bošnjačke uspješne integracije u ovaj okvir [usp. PieniążekMarković 2014 i sl.]. Pa ipak, zapadno-evropska integracija, odnosno sinteza muslimanskog Orijenta i evropskog Zapada te nova, kulturalno otvorena politika identiteta bošnjačke zajednice za Ljubušaka nije imala alternativu, što će uz brojna mjesta u samom tekstu, Ljubušak potvrditi i njegovim motom te završetkom, gdje navodi upravo u ovom smislu simbolične stihove Ivana Mažuranića iz dopunskog, 15. pjevanja spjeva Osman (1826) Ivana Gundulića, kojeg je inače Ljubušak posebno cijenio uprkos antiosmanskoj, pa i antimuslimanskoj idejnoideološkoj provenijenciji ovog baroknog epa: 


\section{Proklet bio tko cić vjere}

Na svojega reži brata!!! [Ljubušak 2008a: 53]

Tako se, manje od desetljeća nakon austrougarske okupacije Bosne, već u slučaju rodonačelnika novije bošnjačke književnosti, u povijesti bošnjačkog viđenja muslimanskog Orijenta i evropskog Zapad javio i tekst koji bi se, uvjetno govoreći, na neki način mogao smatrati i prvim bošnjačkim postkolonijalnim kritičkim radom, barem onda kad su u pitanju pokušaji odgovora na karakteristične orijentalističko-evropocentrične stereotipe s kojima se bošnjačka zajednica suočavala posebno tokom prvih godina nakon njezina ulaska u zapadno-evropski svijet.

No, do uspješne integracije Bošnjaka u evropski Zapad te do njegova pomirenja $s$ muslimanskim Orijentom, kao ni do otvaranja Bošnjaka spram zapadno-evropske kulture i njezinih vrijednosti, nije moglo doći bez da Bošnjaci kao prvenstveni jezik svoje književnosti te uopće javno-pisane komunikacije ne prihvate maternji, bosanski jezik, i to na zapadnoj pismenosti, a što ih je direktno povezivalo s njima srodnim, susjednim narodima, ali i s njihovom književnošću i kulturom, a preko toga i sa zapadno-evropskom kulturom uopće. Mada je ovakvo što značilo i prekidanje dotadašnjeg književnog stvaranja Bošnjaka na orijentalnoislamskim jezicima te alhamijado pismenosti i književnosti, tim ciljem bio je vođen i Ljubušakov u osnovi romantičarski rad na sastavljanju sakupljačkih zbirki Narodno blago i Istočno blago, koje su Bošnjake trebale vratiti upravo njihovu maternjem jeziku, zbog čega kao primjere njihove tradicije na maternjem jeziku u zbirku Narodno blago Ljubušak unosi usmenoknjiževnu baštinu Bošnjaka, prije svega narodne poslovice i druge slične usmenoknjiževne oblike, a u zbirku Istočno blago također poslovice te, uz druge bliske sadržaje, i različite književne forme muslimanskog Orijenta, koje je upravo za potrebe ove zbirke Ljubušak preveo s orijentalno-islamskih jezika. Isti ovaj problem pismenosti i književnog stvaranja Bošnjaka na maternjem, bosanskom jeziku i zapadnoj pismenosti Ljubušak i eksplicitno referira u svoj drugoj brošuri, knjižici Budućnost ili napredak muhamedovaca u Bosni i Hercegovini, gdje posebno naglašava sljedeće:

Nama je Bošnjacima, a osobito na našem materinskom jeziku vrlo lasno naučiti. Naš je jezik i jezgrovit i veoma bogat i naši su stari na našem jeziku, ne budavši im nikakve nužde, još u ono vrijeme po nešto pisali, na primjer Ilhamija iz Travnika, Gaibija iz Zvornika, Kaimija, koji kraj Save u Gradiškom leži. Ti su naši zemljaci mnogo nešta u prozi i u stihovima na našem jeziku pisali. Pogledajmo svršetak one illahije, koju je nedavno napisao šejh Sjekirica sa Oglavka na Kiseljaku, gdje veli:

Nu pogledaj, Sirrije

Sve derviše miluje

I dan i noć kazuje:

La ilahe illalah. [Ljubušak 2008b: 39] 
Ljubušak, naime, podrazumijeva realnu činjenicu neodrživosti kontinuiranja književnog stvaranja Bošnjaka na orijentalno-islamskim jezicima u novim povijesnim uvjetima, ali je i dalje svjestan važnosti tradicije muslimanskog Orijenta za Bošnjake, pa zato podsjeća i na tradiciju bošnjačkog alhamijado književnog stvaranja, pisanog na arebici, ali upravo na bosanskom jeziku, čak je, možda, u nekoj mjeri i prenaglašava u smislu njezine vrijednosti i udjela u dotadašnjoj bošnjačkoj književnoj tradiciji. Ovo podsjećanje za cilj, pritom, ima upravo to da, $s$ jedne strane, ukaže i na jezičku ukorijenjenost Bošnjaka u zapadno-evropskoj kulturi, dok, s druge strane, Ljubušak nastoji potaknuti i ostvarivanje integracije te sinteze muslimanskog Orijenta i evropskog Zapada i u samom jeziku, zbog čega, nesumnjivo ciljano i pažljivo osmišljeno, i spominje istaknute bošnjačke alhamijado stvaraoce te navodi stihove jednog od znamenitih bošnjačkih derviških šejhova čisto religijske, islamske provenijencije. Poruka je jasna: integracija u evropski Zapad ne samo da je egzistencijalno nužna već je i moguća, pa i sasvim prirodna, ona ne predstavlja odbacivanje vlastite tradicije vezane za muslimanski Orijent, već, naprotiv, njezino nastavljanje na novi, novom vremenu primjereniji način, na način sintetskog stapanja s vrijednostima evropskog Zapada, a što je jedina mogućnost koju Bošnjaci imaju žele li ostvariti napredak i sebi samima osigurati sretniju budućnost.

Da kultura evropskog Zapada nije nužno suprotstavljana muslimanskom Orijentu i njegovoj tradiciji kod Bošnjaka, Ljubušak će, napokon, pokazati i svojim originalnim, mada po vrijednostima dosta skromnim književnim radom, iako se kao pisac na orijentalno-islamskim jezicima ostvario prije austrougarske okupacije Bosne, a 1891. godine pokrenuo je i list Bošnjak, prvu vlastitu novinsku publikaciju kod Bošnjaka nakon 1878. godine. Slučajno ili ne, iste godine kad Ljubušak objavljuje brošuru Budućnost ili napredak muhamedovaca u Bosni $i$ Hercegovini sa svojim odlučnim pozivanjem Bošnjaka da prihvate evropski Zapad i njegove vrijednosti, uključujući i povratak maternjem jeziku, njegov sin, Riza-beg Kapetanović (1868-1931), objavit će i pjesničku zbirku Pjesme (1893), prvu cjelovitu pjesničku knjigu jednog Bošnjaka pisanu bosanskim jezikom i zapadnom pismenošću, a u čijem predgovoru mlađahni pjesnik ponavlja u osnovi isti stav prema maternjem jeziku kao i njegov otac $i$ istu potrebu pomirenja tradicije muslimanskog Orijenta i izazova evropskog Zapada.

\section{3.}

$\mathrm{Na}$ ovim i ovakvim osnovama razvijat će se cjelokupna kasnija preporodna književnost Bošnjaka, pri čemu će njezin preporodni karakter upravo podrazumijevati ideje integracije i kulturalne otvorenosti spram vrijednosti evropskog Zapada koje je od samog početka austrougarske okupacije Bosne promovirao Mehmed-beg Kapetanović Ljubušak: ideja preporoda bila je, 
zapravo, upravo ideja prihvatanja zapadno-evropskih vrednota, uz zadržavanje i prilagođavanje i vlastitih vrijednosti kao bošnjačke baštine muslimanskog Orijenta.

Kao i kod Ljubušaka kao rodonačelnika novije bošnjačke književnosti, i kod prve preporodne književne generacije evropski Zapad imaginirat će se prije svega u kontekstu slike progresa i budućnosti, a suštinski duhovni etimon tražit će se i dalje prije svega u muslimanskom Orijentu, kojiće tako postati isvojevrsno mjesto čežnje u bošnjačkoj književnosti s kraja 19. i početka 20. st., ali i kasnije, sve do savremene književne prakse. Ovakvo što sasvim eksplicitno ostvarilo se posebno u književnom djelu Safvet-bega Bašagića, čije će inače prvenstveno pjesničko djelo cjelovito reprezentirati preporodni književno-kulturni program [usp. Rizvić 1990: 282-332; Džanko 2006; Gelez 2010], a što je vidljivo već i u njegovoj prvoj pjesničkoj zbirci Trofanda iz hercegovačke dubrave (1896), koja već svojim naslovom, odnosno simbolikom trofande kao ranog, prvodospijevajućeg voća, sugerira i svoju novinu u književnoj tradiciji Bošnjaka. Bašagić će, naime, u svojoj poeziji, kao i u ukupnom svoje radu, također posebno insistirati na integriranju i sintetiziranju orijentalno-islamskih i zapadno-evropskih vrijednosti i tradicija, pri čemu su u ovom smislu u njegovu pjesničkom opusu posebno simbolički signifikantne dvije pjesme - pjesme Jednome kritičaru i Čarobna kćeri!, koje, kao i kod Ljubušaka, zrcale dva temeljna osjećanja u pogledu odnosa muslimanskog Orijenta i evropskog Zapada kod Bošnjaka.

Pjesma Jednome kritičaru izvorno je objavljena 1903. godine u časopisu $\mathrm{Nada}$, sarajevskom književnom časopisu prohrvatske orijentacije, i predstavlja svojevrsni pjesnikov odgovor na izvjesne kritike upućene njegovu pjesničkom radu, ali i više od toga. U pjesmi, naime, Bašagić definira i književnu tradiciju na koju naslanja svoju poeziju, a to su prije svega književno stvaranje Bošnjaka na orijentalno-islamskim jezicima i bošnjačka usmena književnost, pri čemu neimenovanom kritičaru upućuje eksplicitnu poruku da njegova poezija i nije njemu namijenjena, već, kako kaže, za „gondže-Muju i dilber-Fatu”, dakle za pripadnike vlastite zajednice, a ne za one izvan nje. A kao ovakva, pjesma ukazuje i na i dalje prisutan osjećaj stranstvovanja Bošnjaka u zapadno-evropskom okviru, čak i početkom 20. st., pa čak i na neku vrstu rezignacije koja vodi i mogućnosti kulturalnog autoizolacionizma:

Ti koji ne znaš ozbiljna Arapa, ti koji ne znaš Perzijanca bludna, ti koji ne znaš Turčina-bekriju tebi neće prijat moja pjesma čudna.

Ti što ne ćutiš djevičanske boli narodne pjesme iz naših krajeva, koju Mujo Fati pod pendžerom pjeva tebe moja pjesma nigda ne zagrijeva. 
Što da je čitaš da se dosađivaš, kad ona za te nije ispjevana, već za gondže-Muju, da je dilber-Fati popjeva uz žubor bistra šadrvana.

Pusti je u miru, kad te ne zanima! Ima je ko čitat, jer naš svijet nije pokvario ukus ,s pjevanijom novom', u njemu još tinja iskra poezije. [Bašagić 1903: 34]

No, ovakvo što kod Bašagića samo je trenutna slabost, trenutni manjak vjere u mogućnosti integracije i sinteze muslimanskog Orijenta i evropskog Zapada kod Bošnjaka krajem 19. i početkom 20. st., a kako će to, uz čitav niz drugih mogućih primjera, eksplicitno pokazati druga njegova u ovom kontekstu posebno važna pjesma - pjesma Čarobna kéeri!. Riječje o tipičnoj romantičarskoj apoteozi maternjem jeziku, bošnjačkom ekvivalentu glasovite pjesme Rodu o jeziku Petra Preradovića, ali i pjesmi koja također na svoj način ukazuje na šire prepreke koje su pred Bošnjacima stajale prilikom njihova cjelovitijeg uključivanja u svijet evropskog Zapada. Kao i ranije Ljubušak, i Bašagić se, naime, susreće s pojavom „nacionaliziranja” bosanskih muslimana na njihovu putu ka modernoj Evropi, pa - za razliku od nekih drugih prilika - ovdje svoj jezik imenuje kao hrvatski [usp. Kodrić 2016]. Pa ipak, kao ni Ljubušaka, ni Bašagića ovakvo što ne sprečava u realizaciji preporodnog programa integracije i sinteze muslimanskog Orijenta i evropskog Zapada kod Bošnjaka, te je pjesma vidno obilježena poentom koja je ključna za cjelokupno stanje i odnos Bošnjaka prema muslimanskom Orijentu i evropskog Zapadu krajem 19. i početkom 20. st. - upravo idejom mogućnosti „stapanja” muslimanskog Orijenta i evropskog Zapada:

Čarobna kćeri, prirode majske

Otvori svoje kapije rajske,

O daj me pusti u bajni dvor!

Gdje milo poje pjesmice svoje

Istočnih vila veseli kor.

Da njima kajde u naše pjesme

Slijem, da teku ko rajske česme,

Jer hrvatskog jezika šum

Može da goji

Može da spoji

Istok i zapad, pjesmu i um.

Sad silno huči, ko burno more, Sad blago kao kroz vilin-dvore Tajnih duhova čarobni poj, 


\author{
A sada bruji, \\ Kao da zuji \\ Kroz bašču pčela prognani roj. \\ Sad opet nježno kao da tuži \\ Bulbulče malo na rumen-ruži \\ Jadeći gorko na udes svoj. - \\ Tako se milje \\ I sve se smilje \\ U tebi stapa, jeziče moj! [Bašagić 1896: 80]
}

Ovo i ovakvo spajanje muslimanskog Orijenta i evropskog Zapada Bašagić ostvaruje i širom svojeg književnog djela kao cjeline [usp. Kodrić 2014], a u tom smislu posebno su važne obnove nekih od karakterističnih pjesničko-književnih formi muslimanskog Orijenta, poput npr. gazela, koje Bašagić piše sad i na bosanskom jeziku, ispunjavajući ovu prepoznatljivu formu pjesništva orijentalno-islamskog kruga i specifičnim sadržajima poetike romantizma iz zapadno-evropske tradicije, a što je izrazito važna pojava u njegovoj početničkoj pjesničkoj zbirci Trofanda iz hercegovačke dubrave. U istoj pjesničkoj zbirci te u svojoj narednoj pjesničkoj knjizi, zbirci Misli $i$ čuvstva (1905), Bašagić će objaviti i dva pjesnička spjeva - U Harabatu i Na pučini svjetla, u kojima također spaja orijentalno-islamske i zapadno-evropske tradicijske vrijednosti, te posebno insistira na kombiniranju romantičarskih elemenata i duhovnosti islamskog misticizma, odnosno sufizma ili tesavvufa. Uz slične primjere i u njegovoj narednoj, posljednjoj za života objavljenoj pjesničkoj zbirci, knjizi Izabrane pjesme (1913), ovakvo što svoj svojevrsni klimaks doživjet će u Bašagićevu Mevludu (1924), a koji npr. duboko u prvoj polovini 20. st. i, praktično, u vremenu zapadno-evropske književne avangarde i njezinih različitih inovativnih „izama” na svoj način obnavlja mevludski žanr kao tradicionalnu pjesničku vrstu orijentalnoislamske provenijencije. Riječ je, naime, o poetskom uobličenju onog što je u muslimanskom svijetu poznato pod nazivom „sira” ili „siretur-resuli”, tj. životopis Poslanika islama, Muhammeda, a. s., žanru koji je duboko ukorijenjen prije svega u osmanskoj, pa tako i u bošnjačkoj muslimanskoj tradiciji [usp. Obradović 2000 i sl.], a koji tragom svojih veliki prethodnika, poput npr. hafiza Saliha Gaševića, koji je svoj Mevlud spjevao u vrijeme dovršetka bošnjačke alhamijado pismenosti, Bašagić ispisuje $\mathrm{s}$ mnogim pjesničko-književnim iskustvima pjesnika iz prvih desetljeća zapadno-evropske kulture u Bosni. Na ovaj način, osnovom začete $\mathrm{u}$ Ljubušakovu vremenu, $u$ Bašagićevu slučaju, $u$ svim ovim te drugim brojnim sličnim primjerima, cjelovito će se ostvariti fenomen kulturalno-poetičkih sinkretizma i liminalno-hibridnih oblika, koji će kao jedna od najizrazitijih specifičnosti vidno obilježavati i preporodno književno stvaranje Bošnjaka, ali i sve kasnije povijesnorazvojne faze novije bošnjačke književnosti, počev od 
Ćatićeve moderne pa sve do savremene i recentne bošnjačke književne prakse, u kojoj su također prisutni brojni primjeri susretanja tradicija muslimanskog Orijenta i evropskog Zapada [usp. Kodrić 2014]. U tom smislu, ne bi bez realnog književnohistorijskog utemeljenja bila ni esejistički slobodnija konstatacija da bi bez ovakvih fenomena u ranoj povijesti novije bošnjačke književnosti teško ili barem teže ostvarljive bile i mnoge kasnije u osnovi vrlo slične pojave novije bošnjačke književne prakse poput npr. romana Derviš i smrt (1966) Meše Selimovića kao tek jednog od mogućih primjera ove vrste.

Bašagić, međutim, nije bio samo pjesnik i angažirani bošnjački preporodni kulturalni pregalac, već i vrstan prevodilac s orijentalno-islamskih jezika, ali i stvarni utemeljitelj bošnjačke književne historiografije, odnosno modernog, zapadno-evropski utemeljenog proučavanja bošnjačke književne prošlosti, prije svega bošnjačke književne baštine na orijentalno-islamskim jezicima [usp. Kodrić 2015a], o čemu je u Beču 1910. godine odbranio i doktorsku disertaciju Bosniaken und Hercegovcen auf dem Gebiete der Orientalischen Literatur. I ovaj Bašagićev rad, odnosno kasnija knjiga Bošnjaci i Hercegovci u islamskoj književnosti (1912), počiva na sličnim pretpostavkama, pa će i ovdje, u uvodnim dijelovima knjige, kao neku vrstu svojeg idejnog polazišta Bašagić eksplicitno ponoviti vlastite stihove iz pjesme Čarobna kćeri!, iznova naglašavajući imagologemu o evropskom Zapadu kao mjestu razuma te muslimanskom Orijentu kao mjestu poezije, odnosno srca, ali i važnost njihova pomirenja u kulturnom identitetu Bošnjaka. $S$ ovim u vezi Bašagić novu bošnjačku generaciju podsjeća na „dična imena" narodne prošlosti, koju ne prepošta zaboravu, ali istovremeno konstatira i da su Bošnjaci narod na „granici”, a što susret muslimanskog Orijenta i evropskog Zapada u njihovu slučaju čini nužnim i neizbježnim, ali i plodotvornim, a kako je to uostalom pokazao i njegov vlastiti pjesnički rad:

Sada je pako dužnost mlađeg islamskog naraštaja u Bosni i Hercegovini da ta dična imena dalje predaje, da ta dragocjena djela dalje čuva kao amanete i - gledajući na stari ponos - posegne za istočnom i zapadnom knjigom, pa prema duhu svoga naroda iz oboga stvori nešto novo, jer on stojeći na granici

\author{
Može da goji, \\ Može da spoji \\ Istok i Zapad, pjesmu i um! [Bašagić 1986: 21]
}

Uz ovo, u završnim dijelovima knjige Bošnjaci i Hercegovci u islamskoj književnosti, Bašagić će još izrazitije nego Ljubušak ranije ući u dijalog i s evropocentričnim, odnosno orijentalističkim predstavama o bošnjačkoj kulturi i književnosti, odnosno uopće o Bosni osmanskog doba, posebno s predstavama o „ropskoj” i „tamnovilajetskoj” osmanskoj povijesti Bosne, s čim u vezi također piše: 
Tome ću još da napomenem da ovo djelce nije ništa drugo nego kratka uputa $\mathrm{u}$ jedno poglavlje naše kulturne historije da dokaže onima koji veoma malo, ili nikako nemaju pojma o našoj prošlosti, da su Bosna i Hercegovina do konca XVIII vijeka bile kulturne zemlje i možda kulturnije nego susjedne pokrajine u monarhiji prije 1848. Ishitrena fraza, koja se često čuje od pozvanih i nepozvanih faktora, naime: da je naša domovina za turskog gospodstva čamila u tmini i ropstvu, treba jednom da prestane, jer smo mi do godine 1840. i politički i ekonomski bolje stajali negoli susjedne zemlje, u kojima su dvije trećine pučanstva biće glebae adstricti. Osim toga svrha je ovoj disertaciji da svrati pažnju literarnih historika, kad pišu o Južnim Slavenima, koji su pjevali i pisali u latinskom ili talijanskom jeziku, da progovore koju i o našim zemljacima, koji su pjevali i pisali u arapskom, persijskom ili turskom jeziku. $U$ dvadesetom vijeku vjera ne treba da pravi razliku; prosvjeta je prosvjeta, pa došla ona sa Istoka ili sa Zapada. Jedan Gâibija, kako god je izvojštio odlično mjesto među istočnim spisateljima, da je pisao latinski, isto takovo mjesto u ono doba mogao je izvojštiti u Evropi. Kafija, Nerkesija, Mezakija i dr. isto tako ako ne i više.

Ako mi bude pošlo za rukom od to troje postići barem jedno, smatraću ovu disertaciju korisnim djelom. [Bašagić 1986: 223-224]

I ovdje je, dakle, u pitanju svojevrstan antievropocentrički i antiorijentalistički stav, s tim što Bašagić pravi nesumnjiv iskorak u odnosu na Ljubušaka, pa je njegov diskurs o muslimanskom Orijentu i evropskom Zapadu znatno manje opterećen osjećajem kolonijalne prisile. To, pak, navodi na zaključak da, gledano iz perspektive postkolonijalne teorije i kritike, a s obzirom na odnos muslimanskog Orijenta i evropskog Zapada, bošnjačka kultura, pa tako i književnost u Bašagićevu trenutku izlazi iz svoje naglašeno kolonijalne, adoptivne faze, koju je - očito prolazila u Ljubušakovo vrijeme i polahko se približava narednoj adaptivnoj fazi i tako stvara pretpostavke za završnu, adaptivnu fazu oslobađanja kolonijalnog tereta, što će se, međutim, desiti tek kasnije, nakon Bašagićeva vremena. Za Bašagića, na koncu konca, muslimanski Orijent vrednosno ni u kojem slučaju nije podređen evropskom Zapadu, naprotiv oni su u naporednom odnosu u svakom smislu, pa je zato mogućnost usvajana tekovina zapadno-evropske kulture kod Bošnjaka ne njihov zlosretni usud već, potpuno suprotno, njihova prednost, ali istovremeno i evropski Zapad morao bi Bošnjake prihvatiti kao njima jednake i ravnopravne.

$\mathrm{Na}$ ovaj način, s ovakvim i sličnim razumijevanjima Bošnjaci su, uz muslimanski Orijent, za koji su i dalje ostali neraskidivo vezani, i u književnosti, ali i u humanističkoj nauci, i evropski Zapad prihvatili kao na neki način i svoj. Takvo što bit će slučaj i kod drugih bošnjačkih autora krajem 19. i početkom 20. st., među kojima posebno treba spomenuti i značajne figure kakve su Osman Nuri Hadžić ili Edhem Mulabdić, koji će u bošnjačku književnost uvesti i karakteristični evropski žanr romana, pri čemu će i sami u svojem književnom 
radu oblikovati važne predstave o muslimanskom Orijentu i evropskom Zapadu, ovdje najčešće $u$ okviru tzv. austrougarske teme, tj. upravo teme postosmanskog bosansko-muslimanskog sučeljavanja s modernom Evropom [usp. Kodrić 2012]. Slično Bašagiću, i kod ovih dvaju autora muslimanski Orijent bit će prije svega određen emotivnim aspektom, ali će se budućnost tražiti prvenstveno u vezi s evropskim Zapadom, koji se zato i kod Osmana Nuri Hadžića i kod Edhema Mulabdića nastoji također pomiriti s muslimanskim Orijentom, kako će to biti u slučaj i u njihovim narednim romanima Bez svrhe (1897), odnosno Nova vremena (1914), kao i u ostatku njihovih pripovjedačkih opusa. Književni rad i Osmana Nuri Hadžića i Edhema Mulabdića, kao i drugih autora ovog vremena te većeg broja književnih saputnika, i dalje će se, međutim, odvijati u okvirima folklornog romantizma i prosvjetiteljskog realizma preporodnog doba u bošnjačkoj književnosti, pa će i njihove književne predstave muslimanskog Orijenta i evropskog Zapada biti oblikovane u ovom smislu. No, posebno važan pomak ove vrste desit će se već u pjesničkom djelu Muse Ćazima Ćatića, koji će u bošnjačku književnost prvi uvesti elemente poetike evropske moderne, ali će i među prvima naznačiti elemente još novije, još manje kolonijalno opterećene svijesti kod Bošnjaka, ona koja je već sasvim sigurno adaptivnog karaktera. Mada su njegovi književni počeci praktično bašagićevski, Ćatić u svojoj zreloj pjesničkoj fazi slobodnije komunicira s modernom evropskom kulturom, koju, međutim, vrlo znalački ukršta sa svojim orijentalno-islamskim književno-kulturalnim naslijeđem, sve to bez nekadašnjeg osjećaja prijeke nužnosti hitne prilagodbe novom, evropskom vremenu u Bosni, a što uključuje i nešto drugačiju predstavu muslimanskog Orijenta i evropskog Zapada. Pa ipak, ovaj put srastanja i pune integracije Bošnjaka u zapadno-evropski kontekst trajat će i dalje, sve do danas, kad se Bošnjaci, iako su izvorno ne „azijatski doseljenici” u Bosnu već stari evropski narod kao i njihovi susjedi u Bosni i izvan nje, opet na neki način nalaze pred vratima neke nove, drugačije Evrope. Pri svemu ovom, pogleda li se unatrag na ovaj put, pokazuje se između ostalog i to da je kraj 19. i početak 20. st., odnosno preporodno doba u bošnjačkoj književnosti i kulturi, i vrijeme kad se Bošnjaci počinju imaginirati onako kako se najčešće vide danas - kao narod na raskršću i kao most između muslimanskog Orijenta i evropskog Zapada.

\section{LITERATURA}

[Bašagić 1896] - S. Bašagić, Trofanda iz hercegovačke dubrave, Zagreb.

[Bašagić 1903] - S. Bašagić, Jednome kritičaru, „Nada“, t. 9.

[Bašagić 1986] - S. Bašagić, Bošnjaci i Hercegovci u islamskoj književnosti: Prilog kulturnoj historiji Bosne i Hercegovine, Izabrana djela, knj. III, prir. Džemal Ćehajić i Amir Ljubović, Kulturno nasljeđe Bosne i Hercegovine, Svjetlost, Sarajevo.

[Braun 2009] - M. Braun, Začeci evropeizacije u književnosti slavenskih muslimana u Bosni i Hercegovini, prev. Ibrahim Dizdar i Suada Hedžić, Dobra knjiga, Sarajevo. 
[Ćorović 2008] - V. Ćorović, Mehmed-beg Kapetanović: Književna slika, [u:] Mehmedbeg Kapetanović Ljubušak, Muslimani u Bosni i Hercegovini, prir. Muhidin Džanko, Dobra knjiga, Sarajevo.

[Dukić 1998] - D. Dukić, Figura protivnika u hrvatskoj povijesnoj epici, Hrvatska sveučilišna naklada, Zagreb.

[Džanko 2006] - M. Džanko, Dr. Safvet-beg Bašagić (Mirza Safvet: Vitez pera i mejdana): Intelektualna povijest $i$ ideologijska upotreba djela, Sarajevo Publishing, Sarajevo.

[Geleze 2010] - P. Gelez, Safvet-beg Bašagić (1870-1934): Aux racines intellectuelles de la pensée nationale chez les musulmans de Bosnie-Herzégovine, École française d'Athènes, Atina.

[Isaković 1990] - A. Isaković, prir., O „nacionaliziranju” Muslimana: 101 godina afirmiranja i negiranja nacionalnog identiteta Muslimana, Globus, Zagreb.

[Kodrić 2012] - S. Kodrić, Književnost sjećanja: Kulturalno pamćenje i reprezentacija prošlosti u novijoj bošnjačkoj književnosti, Slavistički komitet, Sarajevo.

[Kodrić 2014] - S. Kodrić, Istok i Zapad - srce $i$ um (Procesi evropeizacije u novijoj bošnjačkoj književnosti i kulturalno-poetički sinkretizmi i liminalno-hibridni oblici kao specifičnost njezina kulturalnog identiteta), [u:] Sarajevski filološki susreti II, Zbornik radova, knj. 2, ur. Sanjin Kodrić, Bosansko filološko društvo, Sarajevo.

[Kodrić 2015a] - S. Kodrić, Utemeljenje moderne bošnjačke književne historiografije: Mehmed-beg Kapetanović Ljubušak i dr. Safvet-beg Bašagić, [u:] Pismo, god. XIII/1, Bosansko filološko društvo, Sarajevo.

[Kodrić 2015b] - S. Kodrić, Preporod prije preporoda? (Pjesma Pozdrav, gospodina hodže Mehmed-Emin-Efendije' i počeci novije bošnjačke književnosti), [u:] Radovi, knj. XVIII, Filozofski fakultet, Sarajevo.

[Kodrić 2016] - S. Kodrić, Preporađanje jezika: Odnos prema maternjem jeziku u bošnjačkoj književnosti kraja 19. i početka 20. stoljeća, [u:] Drugi simpozij o bosanskom jeziku: Zbornik radova, ur. Alen Kalajdžija, Institut za jezik, Sarajevo.

[Ljubušak 2008a] - M. Kapetanović Ljubušak, Što misle muhamedanci u Bosni, [u:] Muslimani u Bosni i Hercegovini, prir. Muhidin Džanko, Dobra knjiga, Sarajevo.

[Ljubušak 2008b] - M. Kapetanović Ljubušak, Budućnost ili napredak muhamedovaca u Bosni i Hercegovini, [u:] Muslimani u Bosni i Hercegovini, prir. Muhidin Džanko, Dobra knjiga, Sarajevo.

[Maglajlić 1987] - M. Maglajlić, Književna djelatnost Mehmed-bega Kapetanovića Ljubušaka, [u:] Mehmed-beg Kapetanović Ljubušak, Narodno blago, Sabrana djela, knj. 1, prir. Munib Maglajlić, Kulturno nasljeđe Bosne i Hercegovine, Svjetlost, Sarajevo.

[Obradović 2000] - Mevlud u životu i kulturi Bošnjaka: Zbornik radova, izbor mevluda, bibliografija, ur. Džafer Obradović, Preporod, Sarajevo.

[Pieniążek-Marković 2014] - K. Pieniążek-Marković, Hrvatski romantičari otkrivaju Bosnu, [u:] Sarajevski filološki susreti II: Zbornik radova, knj. 2, ur. Sanjin Kodrić, Bosansko filološko društvo, Sarajevo.

[Rizvić 1990] - M. Rizvić, Bosansko-muslimanska književnost u doba preporoda (18871918), El-Kalem, Sarajevo. 
Sanjin Kodrić

\title{
HOW DID BOSNIAKS SEE THE MUSLIM ORIENT AND THE EUROPEAN WEST IN THE LATE $19^{\mathrm{TH}}$ AND EARLY $20^{\mathrm{TH}}$ CENTURIES?
}

\author{
(Summary)
}

The paper deals with the representation of the Muslim Orient and the European West in the Bosniak culture, especially literature of the late $19^{\text {th }}$ and early $20^{\text {th }}$ centuries. In this regard, a special focus is placed on the literary and cultural work of Mehmed-bey Kapetanović Ljubušak, the founding father of modern Bosniak literature, and Safvet-bey Bašagić, the cardinal figure in Bosniak literature and culture of the Revival period. Their literary engagement indicates primarily particular efforts to show the Muslim Orient and the European West as not abhorrent to each other but as compatible, thus advocating their convergence and particular fusion in the literature and culture of Bosniaks in the late $19^{\text {th }}$ and early $20^{\text {th }}$ centuries. 